\title{
Studies on the composition of food
}

\section{Some differences in the composition of broiler and free range chickens}

\author{
By JEAN ROBERTSON, MARGARET S. VIPOND,* D. TAPSFIELD† \\ AND J. P. GREAVES \\ Ministry of Agriculture, Fisheries and Food, Great Westminster House, \\ Horseferry Road, London, $S W_{\mathbf{I}}$
}

$$
\text { (Received I } 5 \text { November 1965-Accepted } 26 \text { April 1966) }
$$

\begin{abstract}
I. The nutrient content and distribution of the carcass meat in broilers (B) and free range cockerels (FR) was studied in two experiments in $196 \mathbf{I}-2$. Half the birds of each type were roasted at $I 77^{\circ} \mathrm{C}$, without additional fat, before dissection and analysis. The breast muscles and red meat were separately analysed for moisture, protein, fat and thiamine. 2. Chunky hybrids (frozen) and Light Sussex $\times$ Rhode Island Red (LS $\times$ RIR) cockerels were used in both experiments. Expt 1 (group I) was a pilot study (using groups of six) in which B and FR of similar dressed weight were compared. Expt 2 (group 2 ) consisted of twelve 'fresh' $\left(B_{1}\right)$ and twelve frozen $\left(\mathrm{B}_{2}\right)$ broiler hybrids from the same batch of birds killed at 9 weeks; twelve slightly heavier $\mathrm{LS} \times \mathrm{RIR}$ cockerels $\left(\mathrm{FR}_{2}\right)$ were killed at 18 weeks and twelve Sykes hybrid 3 cockerels $\left(F R_{1}\right)$ killed at 20 weeks. The birds received various standard feeds. 3 . The edible portion (skin plus meat), expressed as a percentage of the dressed weight, was greater in the free range birds than in the broiler chickens. Increased cooking losses resulting from freezing were responsible for a significantly smaller proportion of edible meat in the cooked frozen broilers. In both groups the edible portion increased with age irrespective of breed or weight. 4 . In broiler and free range chickens differences in the mean protein content of the total edible meat were small. 5. Fat content appeared to be related to breed as well as to type of bird. In group I, B contained slightly more fat than FR. In group $2, B_{1}$ and $B_{2}$ contained significantly more fat then $F_{1}$ but the fat content of the raw meat in $\mathrm{FR}_{2}$ was greater. 6 . In both experiments the flesh of the free range chickens contained more thiamine than the broiler meat. In group I this difference was significant in all the cooked birds; in group 2 significant differences between free range chickens and broilers were found in the breast and red meat of the cooked birds for all comparisons except $F_{2}$ and $B_{1}$. About one-third of the thiamine was lost on cooking both types of chicken in group ${ }_{1}$; in group 2 the loss from the broilers was similar but in the FR birds between $18 \%\left(\mathrm{FR}_{1}\right)$ and $26 \%\left(\mathrm{FR}_{2}\right)$ of the thiamine was destroyed. 7 . In general the meat of the broilers contained less thiamine and more fat than did that of the free range chickens. Though such differences are of no significance in a mixed diet (as chicken supplies so little thiamine) they are a useful index of differences in nutritive value which result from the different systems of management.
\end{abstract}

The free range system of husbandry, characterized by the chickens having access to the open air, has been largely superseded by more specialized and intensive methods in which the birds are kept permanently housed. Before 1939 most chickens for the table were reared free range and the usual live weight of a bird for roasting was between 5 and $6 \mathrm{lb}$. Estimates of food supplies available at retail level show that the prewar consumption of poultry in the United Kingdom annually was $5 . \mathrm{I} \mathrm{lb} /$ head; by 1962 consumption had increased to $14.6 \mathrm{lb}$ (Ministry of Agriculture, Fisheries and Food, 1964). This is the result of the introduction of a young intensively produced chicken known as the broiler, which is generally marketed at about $3 \frac{1}{2} \mathrm{lb}$ live weight.

* Present address: Agricultural Research Council, Great Westminster House, Horseferry Road, London, SW $\mathrm{S}$.

$\dagger$ Present address: Ministry of Health, 14 Russell Square, London, WC I. 
The broiler industry has achieved low costs through mass production methods, and this, together with rising standards of living, has led to a rapid increase in the consumption of poultry meat. In June 196I broiler chickens represented about $85 \%$ of the table birds produced (Ministry of Agriculture, Fisheries and Food; Department of Agriculture and Fisheries for Scotland, Ministry of Agriculture, Northern Ireland, I964).

Although there is widespread concern and interest among nutritionists, food technologists and the public about the effects of changing methods of production and processing on the quality (flavour, texture, appearance and nutritive value) of food there is very little information in the literature on the comparative nutritive values of the broiler and free range chickens produced in the United Kingdom. This is in contrast to the numerous published papers concerned with different management systems and their effects on the nutritive state of the birds. A preliminary investigation was therefore made to determine the proximate composition of the edible meat in birds typical of the marketable product of each broad system of management. We could not attempt to examine separately all the regimes and processing methods which may be used. In addition, thiamine was estimated as an index of nutritive value. A brief account of part of this work has been reported (Vipond, Robertson \& Tapsfield, 1964).

The experiments were designed: (a) to compare the composition of (I) broilers with free range cockerels of similar weight, (2) broilers with larger free range cockerels, (3) commercially processed fresh and frozen broilers from the same batch of birds, and $(b)$ to determine the effects of cooking in each instance.

\section{EXPERIMENTAL}

\section{Materials}

Two groups of poultry were used: the first (group I) was purchased in June I96I, the second (group 2) in September-October 1962 . None received hormone treatment. Details of the breeds of birds, age when killed and average dressed weight are summarized in Table $\mathbf{r}$.

Expt $\mathrm{I}$ was a pilot study in which broilers (B) and free range cockerels (FR) of similar dressed weight were compared; the latter were purchased plucked and eviscerated from a family butcher when they were needed for cooking and dissection, and the broiler chickens were male birds processed by the Buxted Chicken Company for retail sale. Six birds reared by each system of management were analysed-three raw and three after cooking; additional information on cooking losses and the distribution of the cooked carcass meat was obtained from a further six birds of each type.

Expt 2 (group 2) was designed to examine the three comparisons detailed above, forty-eight oven-ready chickens supplied by the Spillers Company Research Station at Steeple Aston being used. The birds comprised: twelve (six of each sex) 'fresh' broiler chickens $\left(B_{1}\right)$ and twelve frozen broiler chickens $\left(B_{2}\right)$ from the same batch of birds; twelve small free range Sykes hybrid 3 cockerels $\left(\mathrm{FR}_{\mathbf{1}}\right)$ and twelve slightly heavier free range cockerels $\left(\mathrm{FR}_{2}\right)$ of the Light Sussex $\times$ Rhode Island Red cross (LS $\times \mathrm{RIR}$ ). The hybrid 3 was included as an example of a bird of approximately the 
same weight as a broiler at the age of the LS $\times$ RIR cockerels. Half the birds of each type were dissected and analysed raw; the remainder were roasted before analysis. The dressed carcasses were weighed immediately before dissection or cooking.

\section{Table 1. Chickens studied}

\begin{tabular}{|c|c|c|c|c|c|}
\hline \multirow{2}{*}{\multicolumn{2}{|c|}{ 'Type of chicken }} & \multicolumn{2}{|c|}{ No. of birds } & \multirow{2}{*}{$\begin{array}{c}\text { Age } \\
\text { (weeks) }\end{array}$} & \multirow{2}{*}{$\begin{array}{l}\text { Dressed } \\
\text { wt* }(\mathrm{lb})\end{array}$} \\
\hline & & Male & Female & & \\
\hline \multicolumn{6}{|c|}{ Group I } \\
\hline Chunky hybrid & Frozen B & 12 & - & 10 & $3 \cdot 0$ \\
\hline Light Sussex $\times$ Rhode & & 12 & - & $10-16$ & $2 \cdot 6$ \\
\hline Island Red & Fresh FR & & & & \\
\hline \multicolumn{6}{|c|}{ Group 2} \\
\hline Chunky 7o6 & Frozen $B_{2}$ & 6 & 6 & 9 & $2 \cdot 7$ \\
\hline Sykes hybrid 3 & Fresh $F_{1}$ & 12 & - & 20 & $3 \cdot 4$ \\
\hline $\begin{array}{l}\text { Light Sussex } \times \text { Rhode } \\
\text { Island Red }\end{array}$ & Fresh FR & 12 & 一 & I 8 & $3 \cdot 8$ \\
\hline
\end{tabular}

\section{Frozen broilers}

The processing methods used by the Buxted Chicken Company, to which the broilers (B) in group I were subjected, have been described by Pendry (1960). Production is a continuous operation: after killing, the birds are drawn through a long tank of turbulent water at $\mathbf{1 2} 6^{\circ} \mathrm{F}$, plucked mechanically and then transferred to the evisceration line. Immediately after evisceration and washing the birds are cooled to $40^{\circ} \mathrm{F}$ within $\mathrm{I} 5 \mathrm{~min}$ in a continuous spin chiller by immersion in a mixture of flake ice and water. After cooling, the birds are trussed, the giblets are wrapped and inserted in the body cavity, and the whole birds packed in polythene bags, weighed and labelled. After packaging they pass through freezing tunnels at $-40^{\circ} \mathrm{F}$ for $2 \frac{1}{2} \mathrm{~h}$.

The frozen broilers $\left(\mathrm{B}_{2}\right)$ in group 2 were processed at a commercial packing station, the eviscerated birds being cooled in slush ice for a few hours before blast freezing for a maximum of $4 \mathrm{~h}$.

In both groups the frozen broilers were stored at $-18^{\circ} \mathrm{C}$ until they were needed, thus following the general marketing procedure in the United Kingdom, where the majority of eviscerated broilers are frozen immediately after chilling so that they may be distributed safely through traditional channels in which facilities for refrigeration may be inadequate. When sold to the consumer the carcasses may still be frozen or nearly thawed (Shrimpton, 1960). The American practice of distributing broilers 'fresh' in slush ice or in refrigerated transport is now being used to a limited extent in this country, and for this reason we also analysed twelve 'fresh' broilers $\left(B_{1}\right)$ which had not been subjected to temperatures lower than those of a domestic refrigerator $\left(\mathrm{I}-4^{\circ} \mathrm{C}\right)$.

\section{Method of feeding}

In group I the free range birds were farmyard cockerels whose diet was supplemented by grower pellets and later by fattening pellets; details of the broiler feed were not obtained. 
All the birds in group 2 received standard Spillers feeds as shown in Table 2; these contained the coccidiostat amprolium [I-(4-amino-2-n-propyl-5-pyrimidinylmethyl)2-picolinium chloride hydrochloride] (Merck, Sharp and Dohme Ltd) and their declared composition is shown in Table 3 (Spillers, r965; personal communication). The 'free range' birds were reared in wire-floor pens which allowed access to grass.

Table 2. Method of feeding chickens in group 2

\begin{tabular}{|c|c|c|c|c|}
\hline Type of chicken & Feed I & Feed 2 & Feed 3 & $\begin{array}{l}\text { Total feed } \\
\text { consumed } \\
\text { per bird (lb) }\end{array}$ \\
\hline Chunky 706 & $\begin{array}{l}\text { o-4 weeks } \\
\text { Broiler starter }\end{array}$ & $\begin{array}{l}4-9 \text { weeks } \\
\text { Broiler finisher }\end{array}$ & 一 & $9 \cdot 5$ \\
\hline Sykes hybrid 3 & $\begin{array}{l}\text { o-8 weeks } \\
\text { Chick mash }\end{array}$ & $\begin{array}{l}\text { 8-16 weeks } \\
\text { Grower's mash }\end{array}$ & $\begin{array}{l}\text { 16-20 weeks } \\
\text { Broiler finisher }\end{array}$ & $18 \cdot 0$ \\
\hline $\begin{array}{l}\text { Light Sussex } \times \text { Rhode } \\
\text { Island Red }\end{array}$ & $\begin{array}{l}\text { o-8 weeks } \\
\text { Chick mash }\end{array}$ & $\begin{array}{l}\text { 8-1o weeks } \\
\text { Grower's mash }\end{array}$ & $\begin{array}{l}\text { Io-I } 8 \text { weeks } \\
\text { Broiler finisher }\end{array}$ & $25^{\circ} 0$ \\
\hline
\end{tabular}

Table 3. Composition of feeds used for chickens in group 2

\begin{tabular}{lcccc}
\multicolumn{1}{c}{ Feed } & $\begin{array}{c}\text { Oil } \\
(\mathrm{g} / \mathrm{I00} \mathrm{g})\end{array}$ & $\begin{array}{c}\text { Protein } \\
(\mathrm{g} / \mathrm{I00} \mathrm{g})\end{array}$ & $\begin{array}{c}\text { Fibre } \\
(\mathrm{g} / \mathrm{I} 00 \mathrm{~g})\end{array}$ & $\begin{array}{c}\text { Amprolium } \\
(\mathrm{ppm})\end{array}$ \\
Broiler starter & 3.75 & 23 & $2 \cdot 75$ & $\mathrm{I25}$ \\
Broiler finisher & $4 \cdot 5$ & 19 & $2 \cdot 5$ & $\mathrm{I25}$ \\
Chick mash & 3.0 & 18 & 5.0 & 80 \\
Grower's mash & $3 \cdot 0$ & 16 & $5 \cdot 0$ & 60
\end{tabular}

\section{Cooking procedure}

The frozen broilers were allowed to thaw at room temperature in their polythene bags for about $5 \mathrm{~h}$; the giblets were removed from the body cavity before cooking. In group 2 the procedure was more precisely standardized to reduce the effects of freezing on cooking losses and the birds were cooked immediately they reached $\circ^{\circ} \mathrm{C}$.

The cooked birds were prepared by roasting singly in preheated ovens (without added fat) at a standard oven temperature of $177^{\circ} \mathrm{C}$, which was measured by copper/ constantan thermocouples at frequent intervals.

Cooking time was based on dressed weight allowing $15 \mathrm{~min} / \mathrm{lb}+30 \mathrm{~min}$. The variation between the average cooking time/oz for any group of birds was $\mathrm{I} 5 \mathrm{sec}$ or less.

After cooking, each bird in group I was hung up to drain for $5 \mathrm{~min}$ and in group 2 for ro min; the drip collected during cooking and draining was then weighed. The birds were cooled in a refrigerator overnight, the evaporative loss and drip loss on cooling being determined the following morning. In Expt I (group I) the approximate volume of fat in the collected drip was determined by heating it in a cylinder and measuring the fat which separated out; in Expt 2 the volume of fat was measured after the drip had been centrifuged for $5 \mathrm{~min}$ at $2500 \mathrm{rev} / \mathrm{min}$ (see Table 7).

\section{Dissection}

The breast muscles (pectoralis major and p. minor), red meat (leg, wing and back), skin and bones were separated by dissection and each component was weighed. When estimating the edible portion obtained from the carcass, the skin was included with the flesh. Losses on dissection were minimal and in no instance exceeded $3 \%$ of the 
initial weight; in group 2 the maximum dissection loss was $\mathrm{I} \cdot 9 \%$ of the initial weight. 'Breast blisters' (inflamed bursae at the site of the anterior attachment of the pectoral muscles to the keel), which were present in all the slightly heavier free range birds $\left(\mathrm{FR}_{2}\right)$, were removed, as is normally done before sale, and the skin was sewn up before cooking.

There was no evidence of fatty deposits in the body cavity of the broilers or the free range chickens in group $\mathrm{I}$; deposits of between ${ }_{1} 3$ and $98 \mathrm{~g}$, found in all the raw $B_{1}$ and in one of the $F_{2}$ birds, were discarded with the bone.

\section{Analytical methods}

After dissection, the meat was minced and transferred to a Vortex mixer and pulped. The samples were stored in polythene bottles in a deep freeze $\left(-18^{\circ} \mathrm{C}\right)$ and transferred to a refrigerator the day before analysis.

Duplicate samples of breast meat and red meat were analysed for moisture, protein, fat and thiamine. In group 2 single determinations were also made of the thiamine present in the fat-free drip from the cooked birds.

Volatile matter was determined by drying samples of approximately I $\mathrm{g}$ at $100-\mathrm{IOI}{ }^{\circ} \mathrm{C}$ overnight. Fat was determined in $5 \mathrm{~g}$ samples dried in a vacuum oven overnight at about $40^{\circ} \mathrm{C}$, and extracted in a Soxhlet apparatus for $\mathrm{I} 8 \mathrm{~h}$, using light petroleum ether, b.p. $40-60^{\circ} \mathrm{C}$. The extract was dried for $30 \mathrm{~min}$ at $100^{\circ} \mathrm{C}$, cooled and weighed. Total nitrogen was determined by the improved Kjeldahl method for nitrate-free samples (Association of Official Agricultural Chemists, I960). Thiamine was determined by a method essentially that approved by the Society of Public Analysts and other Analytical Chemists: Analytical Methods Committee (195I), with modifications suggested by Haugen (I960). The homogenized sample was digested with a mixture of the enzymes papain and Takadiastase, and the extracted thiamine oxidized to thiochrome with $\mathrm{K}_{3} \mathrm{Fe}(\mathrm{CN})_{6}$ and $\mathrm{NaOH}$. The thiochrome produced was extracted with isobutyl alcohol $\left(\left(\mathrm{CH}_{3}\right)_{2} \mathrm{CH} . \mathrm{CH}_{2} \mathrm{OH}\right)$ and the fluorescence of the solution measured after irradiation with ultraviolet light. A thiamine standard and blanks were run simultaneously.

\section{RESULTS}

\section{Yield of meat}

The distribution of the carcass meat in the raw and cooked birds is shown in Tables 4-6. When interpreting these results it should be remembered that the broiler and free range birds which are compared had reached different stages of maturity.

It can be seen from 'Table 4 that the edible portion of the carcass expressed as a percentage of the dressed weight was greater in the free range than in the broiler chickens. In group 2 this difference was statistically significant for both $F_{1}$ and $F_{2}$ $(P<0.01)$.

In spite of the precautions taken to reduce the effects of freezing on cooking losses, the proportion of edible meat in the cooked frozen broilers in both experiments expressed as a percentage of the dressed weight was significantly smaller $(P<0.0 \mathrm{I})$ than in the other cooked birds, none of which was frozen (Table 5). 
When the broilers in group $2\left(B_{1}\right.$ and $\left.B_{2}\right)$ were classified on the basis of sex (Table 6 ), the females were considerably lighter than the male birds of the same age, but the proportion of edible meat in the eviscerated female carcass was slightly greater. This general observation has been reported by Hathaway, Champagne, Watts \& Upp (I953), Kondra, Richards \& Hodgson (1962) and others. In all the raw birds in group I the breast meat formed a greater percentage of the edible meat than in those of group 2 ,

\section{Table 4. Yield of meat from raw chickens}

(Mean values with their standard errors)

\begin{tabular}{|c|c|c|c|c|c|}
\hline $\begin{array}{l}\text { Type of } \\
\text { chicken }\end{array}$ & $\begin{array}{l}\text { No. of } \\
\text { chickens }\end{array}$ & $\begin{array}{l}\text { Dressed } \\
\text { wt }(g)\end{array}$ & $\begin{array}{l}\text { Edible portion (EP)* } \\
\text { (\% dressed wt })\end{array}$ & $\begin{array}{l}\text { Breast meat } \\
(\% \mathrm{EP})\end{array}$ & $\begin{array}{l}\text { Red meat } \\
(\% \mathrm{EP})\end{array}$ \\
\hline \multicolumn{6}{|c|}{ Group I } \\
\hline Frozen B & 3 & 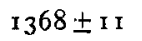 & $48 \cdot 6 \pm 0.9$ & $3^{6 \cdot 1} \pm 0.6$ & $42 \cdot 0 \pm 1 \cdot 3$ \\
\hline Fresh FR & 3 & $1150 \pm 13$ & $5 I \cdot 7 \pm I \cdot 3$ & $35 \cdot 7 \pm 0 \cdot 1$ & $46 \cdot 1 \pm 0.9$ \\
\hline \multicolumn{6}{|c|}{ Group 2} \\
\hline Fresh $B_{1}$ & 6 & $1212 \pm 104$ & $51 \cdot 8 \pm 1 \cdot 0$ & $30 \cdot 1 \pm I \cdot 3$ & $48 \cdot 1 \pm x \cdot 4$ \\
\hline Frozen $B_{2}$ & 6 & $1202 \pm 44$ & $51 \cdot 2 \pm 0.6$ & $30.3 \pm 0.5$ & $46 \cdot 1 \pm 0.5$ \\
\hline Fresh $\mathrm{FR}_{\mathrm{I}}$ & 6 & $1559 \pm 109$ & $59.0 \pm 0.5$ & $32 \cdot 7 \pm 0.8$ & $52 \cdot 3 \pm 0 \cdot 3$ \\
\hline Fresh $\mathrm{FR}_{2}$ & 6 & $1708 \pm 46$ & $55.6 \pm 0.5$ & $30.4 \pm 0.7$ & $49.7 \pm 0.7$ \\
\hline
\end{tabular}

B, broiler; FR, free range (see p. 676).

* That is breast meat + red meat + skin.

Table 5. Yield of meat from cooked chickens

(Mean values with their standard errors)

\begin{tabular}{|c|c|c|c|c|c|}
\hline $\begin{array}{l}\text { Type of } \\
\text { chicken }\end{array}$ & $\begin{array}{l}\text { No. of } \\
\text { chickens }\end{array}$ & $\begin{array}{l}\text { Dressed } \\
\text { wt }(\mathrm{g})\end{array}$ & $\begin{array}{l}\text { Edible portion (EP) } \\
\text { (\% dressed wt) }\end{array}$ & $\begin{array}{c}\text { Breast meat } \\
(\% \text { EP })\end{array}$ & $\begin{array}{l}\text { Red meat } \\
(\% \text { EP) }\end{array}$ \\
\hline \multicolumn{6}{|c|}{ Group I } \\
\hline $\begin{array}{l}\text { Frozen B } \\
\text { Fresh FR }\end{array}$ & $\begin{array}{l}9 \\
9\end{array}$ & $\begin{array}{l}1342 \pm 19 \\
1217 \pm 19\end{array}$ & $\begin{array}{l}40.5 \pm 0.4 \\
44.1 \pm 0.6\end{array}$ & $\begin{array}{l}35 \cdot 1 \pm 0.5 \\
33.6 \pm 0.5\end{array}$ & $\begin{array}{l}47 \cdot 2 \pm 0.7 \\
48 \cdot 0 \pm 0.6\end{array}$ \\
\hline \multicolumn{6}{|c|}{ Group 2} \\
\hline $\begin{array}{l}\text { Fresh } B_{1} \\
\text { Frozen } B_{2} \\
\text { Fresh } F_{1} \\
\text { Fresh } F_{2}\end{array}$ & $\begin{array}{l}6 \\
6 \\
6 \\
6\end{array}$ & $\begin{array}{l}\text { I } 68 \pm 115 \\
\text { I } 302 \pm \text { I } 16 \\
\text { I } 382 \pm 28 \\
\text { I } 720 \pm 34\end{array}$ & $\begin{array}{l}42.8 \pm 0.8 \\
38.9 \pm 0.6 \\
43.8 \pm 0.7 \\
45.5 \pm 0.6\end{array}$ & $\begin{array}{l}30 \cdot 7 \pm I \cdot I \\
31 \cdot 3 \pm 1 \cdot 0 \\
35 \cdot 2 \pm 0 \cdot 8 \\
31 \cdot 0 \pm 0.8\end{array}$ & $\begin{array}{l}50 \cdot 0 \pm 0.6 \\
49 \cdot 6 \pm 1 \cdot 0 \\
49 \cdot 1 \pm 0 \cdot 9 \\
49.5 \pm 1 \cdot 4\end{array}$ \\
\hline
\end{tabular}

$\mathrm{B}$, broiler; FR, free range (see p. 676).

Table 6. Edible portion (EP) of fresh and frozen broilers $\left(B_{1}\right.$ and $\left.B_{2}\right)$ as $\%$ dressed weight, by sex

(Mean values for three birds)

\begin{tabular}{|c|c|c|c|c|c|}
\hline \multirow[b]{2}{*}{ Preparation } & \multirow[b]{2}{*}{ Type of broiler } & \multicolumn{2}{|c|}{ Male } & \multicolumn{2}{|c|}{ Female } \\
\hline & & $\begin{array}{l}\text { Dressed wt } \\
(\mathrm{g})\end{array}$ & $\begin{array}{l}\text { EP } \\
(\%)\end{array}$ & $\begin{array}{c}\text { Dressed wt } \\
(\mathrm{g})\end{array}$ & $\begin{array}{l}\mathrm{EP} \\
(\%)\end{array}$ \\
\hline Raw & $\begin{array}{l}\text { Fresh } B_{1} \\
\text { Frozen } B_{3}\end{array}$ & $\begin{array}{l}1415 \\
1290\end{array}$ & $\begin{array}{l}50 \cdot 16 \\
50 \cdot 58\end{array}$ & $\begin{array}{l}1009 \\
1114\end{array}$ & $\begin{array}{l}53 \cdot 36 \\
51.69\end{array}$ \\
\hline Cooked & $\begin{array}{l}\text { Fresh } B_{1} \\
\text { Frozen } B_{2}\end{array}$ & $\begin{array}{l}\text { I } 425 \\
\text { I } 549\end{array}$ & $\begin{array}{l}41 \cdot 27 \\
37 \cdot 79\end{array}$ & $\begin{array}{r}91 \mathrm{I} \\
\text { IO55 }\end{array}$ & $\begin{array}{l}44 \cdot 52 \\
40.06\end{array}$ \\
\hline
\end{tabular}


but there was no difference in this characteristic between birds of different types or weights within a group. The breast meat of $\mathrm{FR}_{1}$ made up $35 \%$ of the cooked edible portion, $4 \%$ more than in the other birds in group 2 (Table 5). This difference was probably related to breed.

In each experiment the raw free range birds with bigger leg muscles had a higher proportion of red meat than the raw broilers; in group 2 there was a significant difference between free range chickens and broilers $(P<0.02)$ for all comparisons except that between $\mathrm{FR}_{2}$ and $\mathrm{B}_{1}$. In the cooked birds there was no difference, probably because the red meat contained more fat than the breast.

The percentage of skin separated by dissection was slightly lower in the raw free range birds than in the broilers.

\section{Cooking losses}

The losses which determined the weight of cooked meat obtained from the raw oven-ready birds are given in Table 7 . In all the chickens a large proportion of the weight loss was due to the evaporation of water.

In each experiment the frozen broilers lost the greater amount of weight during cooking: the average loss was $19 \%$ of the dressed weight in group I and $27 \%$ in group 2 .

The amount of drip from the smaller free range birds $\left(\mathrm{FR}_{1}\right)$ and the farmyard cockerels (FR) was less than from the other groups, and the proportion of fat in this drip was very much lower. The proportion of fat in the drip from the larger free range birds $\left(F R_{2}\right)$ was not significantly different from that from $B_{1}$ and $B_{2}$.

It can be seen from Table 7 that the proportion of fat in the drip from individual birds was very variable in all the types of chicken examined. As birds in group 2 were allowed to drip for twice as long as those in group $\mathbf{I}$, the weight loss during cooking and the total weight of collected drip in the two groups cannot be directly compared.

\section{Table 7. Losses from chickens roasted at $177^{\circ} \mathrm{C}$}

\begin{tabular}{|c|c|c|c|c|c|}
\hline \multicolumn{6}{|c|}{ (Mean values with their standard errors) } \\
\hline Type of chicken & $\begin{array}{l}\text { No. of } \\
\text { chickens }\end{array}$ & $\begin{array}{l}\text { Wt loss on } \\
\text { cooking ( } \% \\
\text { dressed wt) }\end{array}$ & $\begin{array}{c}\text { Further wt loss } \\
\text { on cooling ( } \% \\
\text { dressed wt) }\end{array}$ & $\begin{array}{c}\text { Total collected } \\
\text { drip ( } \% \\
\text { dressed wt) }\end{array}$ & $\begin{array}{l}\text { Fat in drip } \\
\text { (\% by vol.) }\end{array}$ \\
\hline \multicolumn{6}{|c|}{ Group I } \\
\hline $\begin{array}{l}\text { Frozen B } \\
\text { Fresh FR }\end{array}$ & $\begin{array}{l}9 \\
9\end{array}$ & $\begin{array}{l}18 \cdot 6 \pm 0.4 \\
13 \cdot 2 \pm 0.5\end{array}$ & $\begin{array}{l}2.8 \pm 0.1 \\
2.5 \pm 0.1\end{array}$ & $\begin{array}{l}7 \cdot 2 \pm 0.4 \\
2 \cdot 8 \pm 0 \cdot 3\end{array}$ & $\begin{array}{l}43 \cdot 2 \pm I \cdot 6 \\
27 \cdot 4 \pm 2 \cdot 6\end{array}$ \\
\hline \multicolumn{6}{|c|}{ Group 2} \\
\hline $\begin{array}{l}\text { Fresh } B_{1} \\
\text { Frozen } B_{2} \\
\text { Fresh } F_{1} \\
\text { Fresh } F_{2}\end{array}$ & $\begin{array}{l}6 \\
6 \\
6 \\
6\end{array}$ & $\begin{array}{l}22 \cdot 0 \pm I \cdot 4 \\
27 \cdot 4 \pm 1 \cdot 0 \\
20 \cdot 3 \pm 0 \cdot 5 \\
20 \cdot 2 \pm I \cdot I\end{array}$ & $\begin{array}{l}4.2 \pm 0.2 \\
4.0 \pm 0.3 \\
4.8 \pm 0.2 \\
3.7 \pm 0.2\end{array}$ & $\begin{array}{l}8 \cdot 2 \pm r \cdot I \\
8 \cdot 8 \pm 0.9 \\
4 \cdot 2 \pm 0.5 \\
6 \cdot 3 \pm 0.6\end{array}$ & $\begin{array}{l}57 \cdot 3 \pm 7 \cdot 1 \\
60 \cdot 3 \pm 3 \cdot 8 \\
26 \cdot 7 \pm 6 \cdot 1 \\
58 \cdot 4 \pm 5 \cdot 8\end{array}$ \\
\hline
\end{tabular}

$B$, broiler; FR, free range (see p. 676).

\section{Nutrient content}

The average results of the chemical analyses for each type of bird are summarized in Tables 8-10. In Tables 8 and 9 the results are expressed separately in terms of breast and red meat, and in Table Io the nutrient content of the total meat (excluding skin) has been calculated. All the results are expressed on a moist-weight basis. 
As only three birds of each type were analysed in group $I$, an overall comparison between the broiler chickens and the free range birds in both experiments was not justified.

\section{Table 8. Chemical analyses of raw chicken meat}

(Mean values with their standard errors)

\begin{tabular}{|c|c|c|c|c|c|}
\hline $\begin{array}{l}\text { Type of } \\
\text { chicken }\end{array}$ & $\begin{array}{c}\text { Type of } \\
\text { meat }\end{array}$ & $\begin{array}{l}\text { Moisture } \\
\text { (g/100 g) }\end{array}$ & $\begin{array}{c}\text { Protein } \\
(\mathrm{N} \times 6 \cdot 25) \\
(\mathrm{g} / \mathrm{I} 00 \mathrm{~g})\end{array}$ & $\begin{array}{c}\text { Fat } \\
(\mathrm{g} / \mathrm{l} 00 \mathrm{~g})\end{array}$ & $\begin{array}{l}\text { Thiamine } \\
(\mu \mathrm{g} / \mathrm{x} 00 \mathrm{~g})\end{array}$ \\
\hline \multicolumn{6}{|c|}{ Group I (mean values for three chickens) } \\
\hline Frozen B & $\begin{array}{l}\text { Breast } \\
\text { Red }\end{array}$ & $\begin{array}{l}74 \cdot 3 \pm 0 \cdot 2 \\
74 \cdot 1 \pm 1 \cdot 3\end{array}$ & $\begin{array}{l}23.6 \pm 0.5 \\
20.1 \pm 0.2\end{array}$ & $\begin{array}{l}2 \cdot 0 \pm 0 \cdot 6 \\
6 \cdot 0 \pm 1 \cdot 8\end{array}$ & $\begin{array}{l}56 \pm 8 \\
63 \pm 8\end{array}$ \\
\hline Fresh FR & $\begin{array}{l}\text { Breast } \\
\text { Red }\end{array}$ & $\begin{array}{l}73 \cdot 0 \pm 0.3 \\
72 \cdot 7 \pm 0.6\end{array}$ & $\begin{array}{l}22 \cdot 9 \pm 0.8 \\
21 \cdot 3 \pm 0.2\end{array}$ & $\begin{array}{l}I .3 \pm 0.5 \\
4.8 \pm 0.9\end{array}$ & $\begin{array}{r}83 \pm 10 \\
108 \pm 17\end{array}$ \\
\hline
\end{tabular}

Group 2 (mean values for six chickens; where fewer are used the number is shown in parentheses)

$\begin{array}{llllll}\text { Fresh } B_{1} & \text { Breast } & 74.6 \pm 0.3 & 23.0 \pm 0.2 & 0.93 \pm 0.10 & 37 \pm 4(2) \\ & \text { Red } & 74.5 \pm 0.3 & 19.7 \pm 0.2 & 5.00 \pm 0.36 & 44 \pm 2(3) \\ \text { Frozen } B_{2} & \text { Breast } & 73.8 \pm 0.2 & 26.0 \pm 0.2 & 0.71 \pm 0.07 & 38 \pm 2(4) \\ & \text { Red } & 74.5 \pm 0.5 & 22.4 \pm 0.3 & 5.25 \pm 0.45 & 35 \pm 0.5(4) \\ \text { Fresh FR } & \text { Breast } & 74.1 \pm 0.3 & 23.5 \pm 0.4 & 0.43 \pm 0.07 & 57 \pm 4(5) \\ & \text { Red } & 75.5 \pm 0.3 & 20.8 \pm 0.5 & 2.33 \pm 0.22 & 62 \pm 4(5) \\ \text { Fresh FR } & \text { Breast } & 73.8 \pm 0.1 & 26.6 \pm 0.1(5) & 1 \cdot 10 \pm 0.17 & 39 \pm \pm(5) \\ & \text { Red } & 72 \cdot 0 \pm 0.5(5) & 22.5 \pm 0.3 & 6.96 \pm 0.46 & 50 \pm 3(5)\end{array}$

B, broiler; FR, free range (see p. 676).

\section{Table 9. Chemical analyses of cooked chicken meat}

(Mean values with their standard errors)

\begin{tabular}{|c|c|c|c|c|c|}
\hline $\begin{array}{l}\text { Type of } \\
\text { chicken }\end{array}$ & $\begin{array}{l}\text { Type of } \\
\text { meat }\end{array}$ & $\begin{array}{l}\text { Moisture } \\
(\mathrm{g} / \mathrm{l} 00 \mathrm{~g})\end{array}$ & $\begin{array}{r}\text { Protein } \\
(\mathrm{N} \times 6.25) \\
(\mathrm{g} / 100 \mathrm{~g})\end{array}$ & $\begin{array}{c}\text { Fat } \\
(\mathrm{g} / 100 \mathrm{~g})\end{array}$ & $\begin{array}{l}\text { Thiamine } \\
(\mu \mathrm{g} / \mathrm{l} 00 \mathrm{~g})\end{array}$ \\
\hline \multicolumn{6}{|c|}{ Group I (mean values for three chickens) } \\
\hline \multirow[t]{2}{*}{ Frozen B } & Breast & $67 \cdot 7 \pm 0.3$ & $28 \cdot 0 \pm 0 \cdot 7$ & $3 \cdot 1 \pm 0.6$ & $34 \pm 1$ \\
\hline & Red & $68 \cdot 3 \pm 0 \cdot 2$ & $22 \cdot 9 \pm 0 \cdot 1$ & $8 \cdot 1 \pm 0.4$ & $43 \pm 7$ \\
\hline \multirow[t]{2}{*}{ Fresh FR } & Breast & $67 \cdot 9 \pm 0.4$ & $28 \cdot 7 \pm 0.5$ & $2 \cdot 4 \pm 0 \cdot 3$ & $59 \pm 8$ \\
\hline & Red & $69 \cdot 0 \pm 0.4$ & $23 \cdot 3 \pm 0.5$ & $6.6 \pm 0.4$ & $7 \pm \pm 3$ \\
\hline
\end{tabular}

Group 2 (mean values for six chickens; where fewer are used the number is shown in parentheses)

\begin{tabular}{|c|c|c|c|c|c|}
\hline Fresh $B_{1}$ & $\begin{array}{l}\text { Breast } \\
\text { Red }\end{array}$ & $\begin{array}{l}67.5 \pm 0.3 \\
65.4 \pm 0.6\end{array}$ & $\begin{array}{l}30.3 \pm 0.4 \\
27.4 \pm 0.3\end{array}$ & $\begin{array}{l}2 \cdot 85 \pm 0.40 \\
8 \cdot 16 \pm 0.70\end{array}$ & $\begin{array}{l}25 \pm 1(3) \\
29 \pm 3(4)\end{array}$ \\
\hline Frozen $\mathrm{B}_{2}$ & Breast & $65.3 \pm 0.3(5)$ & $32 \cdot 0 \pm 0 \cdot 3(5)$ & $2.49 \pm 0.18$ & $22 \pm 2(4)$ \\
\hline & Red & $64 \cdot 5 \pm 0 \cdot 4$ & $26 \cdot 9 \pm 0.4$ & $8 \cdot 3^{6} \pm 0.50$ & $27 \pm 1($ \\
\hline Fresh $F_{1}$ & $\begin{array}{l}\text { Breast } \\
\text { Red }\end{array}$ & $\begin{array}{l}67.5 \pm 0.3 \\
66.5 \pm 0.4(4)\end{array}$ & $\begin{array}{l}31.4 \pm 0.4 \\
29.6 \pm 0.2\end{array}$ & $\begin{array}{l}I \cdot 14 \pm 0.14 \\
4 \cdot 14 \pm 0.28\end{array}$ & $\begin{array}{l}43 \pm 2 \\
53 \pm 5\end{array}$ \\
\hline Fresh $\mathrm{FR}_{2}$ & $\begin{array}{l}\text { Breast } \\
\text { Red }\end{array}$ & $\begin{array}{l}67.3 \pm 0.6 \\
64.4 \pm 0.8\end{array}$ & $\begin{array}{l}3 I \cdot 6 \pm 0.3 \\
28 \cdot 0 \pm 0 \cdot 3(5)\end{array}$ & $\begin{array}{l}2 \cdot 56 \pm 0.37 \\
8 \cdot 33 \pm 0.68\end{array}$ & $\begin{array}{l}33 \pm 1 \\
35 \pm 2\end{array}$ \\
\hline
\end{tabular}

B, broiler; FR, free range (see p. 676).

Protein. Differences in the mean protein content of the total edible meat in broiler and free range chickens were small. The breast meat of all types of birds contained slightly more protein than the red meat.

We have used a conversion factor of $6 \cdot 25$ for the calculation of crude protein from nitrogen in both broilers and free range birds. Detailed experiments by Khan ( 1962 ) 
on the extraction and fractionation of proteins in fresh chicken muscle suggest that the amounts of the protein components in breast and leg muscle change with the age of the bird, and also differ with breed, nutritional state and pre- and post-slaughter conditions; thus the factor 6.25 may not be ideal for comparisons between different types of birds.

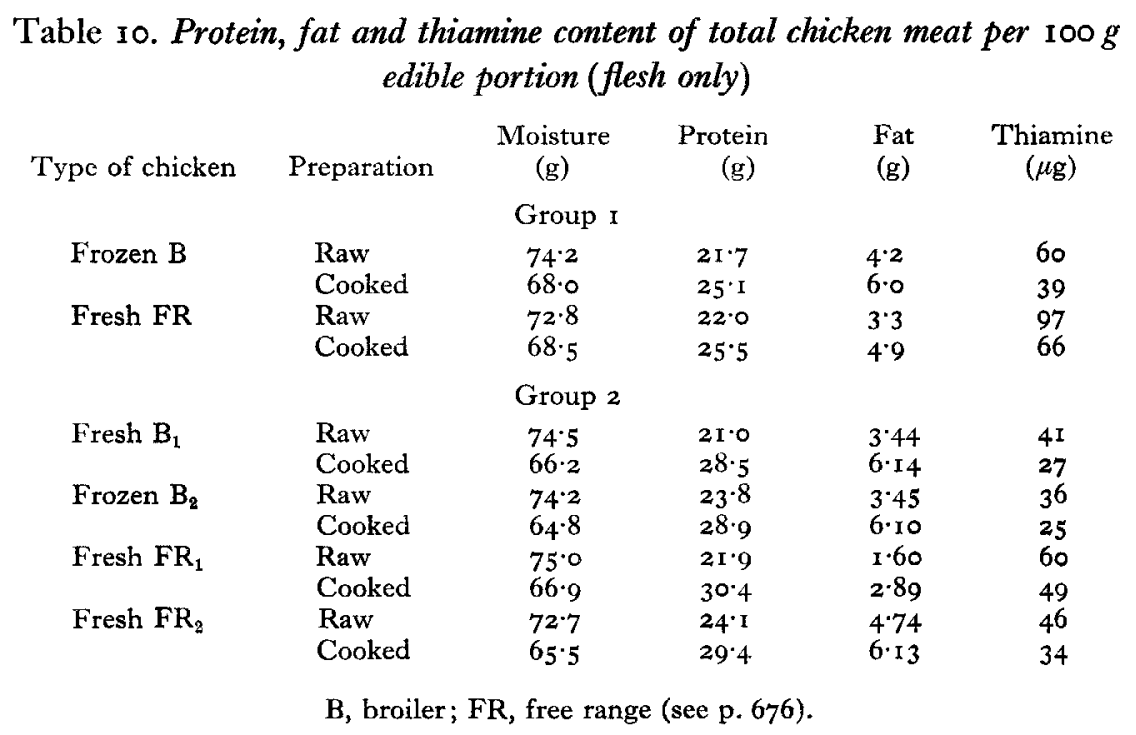

Fat. In group I, both raw breast and red meat of the broilers (B) contained slightly more fat than in the free range cockerels (FR). The raw breast and red meat of the broilers $\left(B_{1}\right.$ and $\left.B_{2}\right)$ in group 2 contained significantly more fat than in the Sykes hybrid 3 group $\left(\mathrm{FR}_{1}\right)$ (breast, $P<0.02$; red meat, $P<0.001$ ), but rather less than in the slightly heavier free range cockerels $\left(\mathrm{FR}_{2}\right)($ Table 8$)$.

With the exception of $\mathrm{FR}_{2}$ the mean differences observed between the raw broilers and free range cockerels were accentuated by cooking (Table 9 ).

The fat content of the red meat was markedly higher than that of the breast in all birds.

Thiamine. Both broiler chickens and free range chickens in group I contained more thiamine than the corresponding type of bird in group 2 (Table ro).

In both experiments the flesh of the free range chickens contained more thiamine than the broiler meat. For the raw meat, whereas the observed differences did not attain statistical significance in group I, in group 2 the level of thiamine in both the red and breast meat of $\mathrm{FR}_{1}$ was significantly higher than that in the corresponding broiler $\left(\mathrm{B}_{1}\right.$ and $\left.\mathrm{B}_{2}\right)$ meats $(P<0.05)$, and for the comparison between the red meat of $\mathrm{FR}_{2}$ and $\mathrm{B}_{2}$ the difference was also significant $(P<0.01)$ (Table 8). For the cooked birds in group $\mathrm{I}$ this difference was significant in the breast and red meat $(P<0.05)$. In group 2 significant differences $(P<0 \cdot 01)$ between free range chickens and broilers were found in the breast and red meat of the cooked birds for all comparisons except for that between the red meat of $\mathrm{FR}_{2}$ and $\mathrm{B}_{1}$ (Table 9). The red meat in the cooked 
birds of all the types and breeds examined contained slightly more thiamine than the breast.

About one-third of the thiamine was lost on cooking both types of chicken in group $\mathrm{I}$; in group 2 there was a similar loss from the broilers, but in the free range birds between $18 \%\left(\mathrm{FR}_{1}\right)$ and $26 \%\left(\mathrm{FR}_{2}\right)$ of the thiamine was on average destroyed. In the three groups in which the thiamine content of the fat-free drip was estimated, the concentration of thiamine in the drip was similar to that in the cooked meat.

\section{DISCUSSION}

\section{Edible meat}

When discussing the yield of meat obtained from different types of chicken, care must be taken to ensure that the results are expressed in comparable terms. In many American studies, giblets are included in the weight of 'edible meat' and the 'dressed bird ' may be plucked but not eviscerated. In our experiments the 'dressed weight' is the eviscerated weight of the raw bird, which excludes the giblets.

Brown \& Bean (1952), examining the amount of edible meat (skin, meat and giblets) in five different market classes of chickens, varying from 2 to $6.8 \mathrm{lb}$ live weight, concluded that there was no great difference in the percentage yield of edible material from any weight or type of bird. Morrison, Sauter, McLaren \& Stadelman (I954) also found no consistent differences in the yields of edible meat obtained from eight varieties of broiler birds killed at 12 weeks. The values we obtained were for skin plus meat only, expressed as a percentage of the dressed weight. On this basis, the edible portion in both groups increased with age but, as in the studies mentioned, did not seem to be related to breed or weight (Tables I and 4 ).

\section{Nutrient content: published data}

Information on the nutrient content of chickens extracted from tables of food composition published in the United Kingdom and the United States is summarized in Table II.

The proximate composition of pectoral muscle in raw chicken (McCance $\&$ Widdowson, 1960) is similar to the composition obtained for the breast meat of frozen broilers in group $I$ in this experiment. No indication is given of the numbers of samples analysed or the type of chicken from which the muscle was taken.

The recently revised USDA Agriculture Handbook No. 8 (Watt \& Merrill, I963) contains detailed analyses for the fryer class of chickens. The results are based on forty-eight male birds of the Vantress $\times$ Arbor Acres cross slaughtered at Io w eeks, with an average dressed weight of only $2 \cdot \mathrm{I} l \mathrm{lb}$ (without giblets). The moisture content of the flesh is higher than in any of the slightly heavier birds of the same age which we examined. The fat content of the breast is not very different from that of $B, B_{1}$ and $B_{2}$, but the percentage of fat in the red meat is lower in the American birds than in the Chunky 706 hybrid. The thiamine content of the meat of the Vantress $\times$ Arbor Acres birds is similar to that of the broiler chicken in group $\mathbf{I}$. 


\section{Fat}

In our experiments the skin, which is rich in fat, was not analysed. Variable amounts of fat were found in the flesh of broilers and free range chickens; the differences obtained appeared to be related to breed as well as to the type of bird, rather than to age or weight. Davidson, Mathieson, Williams \& Boyne (1964), using birds of the same age ( 12 weeks) showed that on a given diet cockerels of a modern commercial fast-growing hybrid strain tended to contain a greater percentage of fat and less water than cockerels of a Rhode Island Red $\times$ Light Sussex cross. The authors state that more recent unpublished work at the Rowett Research Institute indicates that the broiler birds may still contain more fat than the Rhode Island Red $\times$ Light Sussex cross when killed at the same weight. Pudelkewicz, Gordon \& Kahlenberg (1963), comparing 9-week-old broilers in deep litter with those reared on wire screens, found that the birds maintained on built-up litter had smaller fat stores. In contrast to this Gilpin, Harkin, Redstrom \& Dawson (r960), using birds of similar live weight, showed that drumsticks from slow-growing Barred Plymouth Rocks fed on a regime typical of I930, and given access to grass after 4 weeks, had a higher fat content than those from the New Hampshire $\times$ Silver Cornish cross which were confined throughout growth and fed on rations representative of 1956 .

\section{'Table I I. Nutrient content of chicken in published food tables}

(Per roog edible portion)

\begin{tabular}{|c|c|c|c|c|}
\hline Description of sample & $\begin{array}{c}\text { Moisture } \\
\text { (g) }\end{array}$ & $\begin{array}{l}\text { Protein } \\
\text { (g) }\end{array}$ & $\begin{array}{l}\text { Fat } \\
\text { (g) }\end{array}$ & $\begin{array}{c}\text { Thiamine } \\
(\mu \mathrm{g})\end{array}$ \\
\hline \multicolumn{5}{|l|}{ British } \\
\hline Chicken raw, pectoral muscle only* & $73 \cdot 7$ & $23 \cdot 2$ & $2 \cdot 1$ & 100 \\
\hline Chicken roast, with basting* & $6 I \cdot I$ & $29^{\cdot 6}$ & $7 \cdot 3$ & 50 \\
\hline Fowl, raw, plucked and drawn $\nmid$ & $73^{-0}$ & $18 \cdot 0$ & $7 \cdot 0$ & 150 \\
\hline \multicolumn{5}{|l|}{ American $\ddagger$} \\
\hline Broilers, broiled, flesh only & $7 r \cdot 0$ & $23 \cdot 8$ & 3.8 & 50 \\
\hline \multicolumn{5}{|l|}{ Chicken (all classes) } \\
\hline Light meat without skin, raw & $73 \cdot 7$ & $23 \cdot 4$ & $I \cdot 9$ & 50 \\
\hline Light meat without skin, roasted & $63 \cdot 8$ & $31 \cdot 6$ & $3 \cdot 4$ & 40 \\
\hline Dark meat without skin, raw & $73 \cdot 7$ & $20 \cdot 6$ & $4 \cdot 7$ & 80 \\
\hline Dark meat without skin, roasted & $64 \cdot 4$ & $28 \cdot 0$ & $6 \cdot 3$ & 70 \\
\hline \multicolumn{5}{|c|}{$\begin{array}{l}\text { Fryers (Vantress } \times \text { Arbor Acres cross, } \\
\text { Io weeks. Mean values for forty-eight birds) }\end{array}$} \\
\hline Light meat without skin, raw & $77 \cdot 2$ & $20 \cdot 5$ & $1 \cdot 5$ & 50 \\
\hline Dark meat without skin, raw & $77 \cdot 3$ & I $8 \cdot 1$ & 3.8 & 60 \\
\hline Flesh only, raw & $77 \cdot 2$ & I9:3 & $2 \cdot 7$ & 60 \\
\hline \multicolumn{5}{|l|}{ Roasters } \\
\hline Flesh only, raw & $73 \cdot 3$ & $2 I \cdot I$ & $4 \cdot 5$ & 100 \\
\hline Flesh only, roasted & $62 \cdot 8$ & $29 \cdot 5$ & $6 \cdot 3$ & 100 \\
\hline Light meat without skin, raw & $72 \cdot 3$ & $23 \cdot 3$ & $3 \cdot 2$ & 80 \\
\hline Light meat without skin, roasted & $61 \cdot 3$ & $32-3$ & 49 & 80 \\
\hline Dark meat without skin, raw & $73 \cdot 2$ & $2 I \cdot 0$ & $4 \cdot 7$ & I 30 \\
\hline Dark meat without skin, roasted & $62 \cdot 7$ & $29 \cdot 3$ & $6 \cdot 5$ & I 20 \\
\hline
\end{tabular}

* McCance \& Widdowson (rg6o). † Medical Research Council (1945). $\ddagger$ Watt \& Merrill (1963).

It would appear that the combined effects of diet and management practices, breed, age and weight on the level of fat in the tissues need further clarification. 


\section{Thiamine}

Pudelkewicz et al. ( 1963 ) have reviewed the literature on the thiamine content of raw breast and red meat in birds of different types and ages. The values reported suggest that the thiamine content of all chicken flesh increases with age; thus the fast-growing hybrid broiler strains contain less thiamine than slower-growing free range birds of approximately the same weight. This trend was also suggested by our results.

The feeds used for the birds in group 2 contained different levels of amprolium (Table 3 ), but all the birds were finished on broiler finisher. Polin, Wynosky \& Porter ( $1962 a, b, 1963 a, b)$ have shown that the coccidiostat amprolium competes with thiamine for absorption from the intestine. It is capable of producing thiamine deficiency in chicks, adult poultry and eggs, but only when added at levels in excess of $700 \mathrm{ppm}$ to diets containing approximately $5^{-6} \mathrm{ppm}$ thiamine. The level of amprolium tolerated is increased if thiamine is added to the feed. The authors do not make any observations on the effects of different levels of amprolium on the thiamine content of the tissues of adult birds, and we do not know if the differences in thiamine content which we report in this paper can in any way be attributed to the coccidiostat.

\section{General}

The results reported in this paper show that in general the meat of the broiler chickens contained less thiamine and more fat than that of the free range chickens. Such differences are, however, of no material significance in relation to the thiamine content of a balanced diet. For example, the Annual Report of the National Food Survey Committee for 1963 (Ministry of Agriculture, Fisheries and Food: National Food Survey Committee, I965) shows that in the average household diet poultry supplied only $0.7 \%$ of the total thiamine compared with $26.9 \%$ from bread and flour and $16.3 \%$ from carcass meat and bacon. Nevertheless, it cannot be denied that differences in the nutritional values of broiler and free range chickens can exist.

It may possibly be objected that observations of the type reported in this paper are of limited significance because the many factors that influence the results-breed, sex, age, weight, feed-have not been sufficiently controlled to enable their individual roles to be precisely evaluated. Such, however, was not our objective-though of course an evaluation of this kind is essential for the full interpretation of observations such as ours. Rather, we were concerned with the pragmatic problem of estimating, in terms of the availability of nutrients to the consumer, the net result of the various combinations of factors which together constitute a 'system of management'. To argue, as one might, that results are vitiated because, say, the age of the birds under System $\mathrm{X}$ was different from that under System $\mathrm{Y}$ is in this context irrelevant if one of the features of System $\mathrm{X}$ is to produce birds for slaughter at a younger age than can be done, or is in practice done, by System Y. Indeed, it is the system as a whole, rather than any single feature of it, that is being investigated.

There is a wider context in which such investigations should be considered, a context which includes an appreciation of the economic factors involved, a costing of ultimate yields in terms of time, money or material resources, that we have not 
attempted. The observations reported in this paper, and others of a similar type, must not be supposed to provide evidence in themselves sufficient to condemn or condone a particular system. Such a judgement can only be made in the full context, however hazardous the evaluations required, but while observations of this kind are not sufficient they do provide a necessary part of the total evidence on which a judgement may properly be based.

We are grateful to the Buxted Chicken Co. Ltd, Fulk Bros. (Butchers) and Spillers Ltd, Animal Nutrition Research Laboratory, for supplying the birds used in these experiments; also to Miss M. A. Chambers for technical assistance.

\section{REFERENCES}

Association of Official Agricultural Chemists (1960). Official Methods of Analysis, 9th ed. Washington, DC: Association of Official Agricultural Chemists.

Brown, P. B. \& Bean, H. W. (1952). Poult. Sci. 31, 232.

Davidson, J., Mathieson, J., Williams, R. B. \& Boyne, A. W. (1964). F. Sci. Fd Agric. r5, 316.

Gilpin, G. L., Harkin, A. M., Redstrom, R. A. \& Dawson, E. H. (1960). Poult. Sci. 39, 924.

Hathaway, H. E., Champagne, G. B., Watts, A. B. \& Upp, C. W. (1953). Poult. Sci. 32, 968.

Haugen, H. N. (1960). Scand. F. clin. Lab. Invest. r2, 253.

Khan, A. W. (1962). F. Fd Sci. 27, 430.

Kondra, P. A., Richards, J. F. \& Hodgson, G. C. (1962). Poult. Sci. 4r, 922.

McCance, R. A. \& Widdowson, E. M. (1 960). Spec. Rep. Ser. med. Res. Coun., Lond. no. 297.

Medical Research Council (I945). Med. Res. Coun. War Memo. no I4.

Ministry of Agriculture, Fisheries and Fond (1964). Board of Trade Fournal $\mathbf{1 8 7}, 742$.

Ministry of Agriculture, Fisheries and Food: National Food Survey Committee (1965). Domestic Food Consumption and Expenditure: 1963 . London: H.M. Stationery Office.

Ministry of Agriculture, Fisheries and Food; Department of Agriculture and Fisheries for Scotland, Ministry of Agriculture, Northern Ireland (1964). Agricultural Statistics $1961 / 62$, United Kingdom Agricultural Censuses of Production. London: H.M. Stationery Office.

Morrison, M. A., Sauter, E. A., McLaren, B. A. \& Stadelman, W. J. (1954). Poult. Sci. 33, I 22.

Pendry, A. R. (1960). R. Soc. Hlth $¥ .80$, I32.

Polin, D., Wynosky, E. R. \& Porter, C. C. (1962a). F. Nutr. 76, 59.

Polin, D., Wynosky, E. R. \& Porter, C. C. $(1962 b)$. Proc. Soc. exp. Biol. Med. r1o, 844.

Polin, D., Wynosky, E. R. \& Porter, C. C. $(1963$ a). Poult. Sci. 42, 1057.

Polin, D., Wynosky, E. R. \& Porter, C. C. $(1963$ b). Proc. Soc. exp. Biol. Med. rr4, 273.

Pudelkewicz, C., Gordon, H. W. \& Kahlenberg, O. J. (1963). Poult. Sci. 42, 843.

Shrimpton, D. H. (1960). Br. Poult. Sci. I, ror.

Society of Public Analysts and other Analytical Chemists: Analytical Methods Committee (I95I). Analyst 76, I27.

Vipond, M. S., Robertson, J. \& Tapsfield, D. (1964). Proc. Nutr. Soc. 23, xxxviii.

Watt, B. K. \& Merrill, A. L. (1963). Composition of Foods, Handbook no. 8. Washington, DC: USDA Agricultural Research Service. 